\title{
WRITING FOR PUBLICATION: IF SO, WHY? IF NOT NOW, WHEN?
}

\author{
Jerome Beker, \\ University of Minnesota
}

\begin{abstract}
As child and youth care workers, we need to be able to tell our story - and our stories - and there are various ways in which we can do so. This article describes the importance of what we have to say, why it needs to be in writing, who might be interested, and where and in what form it might appear. Practical help is available. Interested readers are encouraged to start now!
\end{abstract}

As Mike Baizerman (1987) has reminded us, much of our work in child and youth care is talk; it is poetry in motion, improvisation as in jazz. It is spontaneous - but not random - unfolding, open-ended, the flow of life. Writing, on the other hand, stops the action, freezes the frame, forecloses possibilities for change. Therefore, many of us in child and youth care work prefer to talk rather than to write, to be (and to be ourselves), rather than to do what we do by formula or by rote. This goes to the heart of the ambivalence of many of us toward the idea of professionalism, at least as it is frequently understood, and to why some have proposed the concept of craft as an appropriate organizing metaphor for the field (e.g., Eisikovitz \& Beker, 1983). Yet few would hold that there are no underlying principles in our work. To observe that the work of a craftsperson reflects the essence and authenticity of his or her being, rather than a rote application of a production formula, is not to say that there are no common principles involved. Nor is our work narcissistic, in the sense that we and what we do are all that matter. Rather, it is rooted firmly in a concept of service to some of the neediest among us, our young people. We are intensely connected, thereby, to the whole of the human condition and responsible in the most profound sense to all of humanity. To say that, in a significant way, the world depends on us might sound a bit too self-important, but it may still be true!

All this carries the additional responsibility, as Karen VanderVen (1988) has observed, to record what we do. That seems, however, to be where many of us begin to withdraw, to leave the task to others. Under the pressure of our daily responsibilities, seemingly always with too little help to meet immediate needs, we let time get away from us. And 
we sometimes feel that "they" - the agency authorities, government authorities, the public, the "system" - may use the information against us, or at least that they won't understand what we are doing or why.

As a result, we worry that what we can do may be constrained (even more than it is now), and that the spontaneity on which we depend may be lost as a result. "Research" may be used as the basis for mandating processes and procedures without a full understanding of the nuances that, many of us believe, can never be studied systematically. Better to focus on what we do in our direct work with children and youth; that in itself takes more time and energy than we can maintain, anyway.

From another perspective, however, writing can be viewed as how we tell our story. As do many of the young people with whom we work, each of us who has been in the field for even a relatively short period of time has a story - or stories - of great human interest to tell.

\section{THE IMPORTANCE OF STORIES}

There has been growing recognition in recent decades of the therapeutic importance of people's stories and of their having the opportunity to tell them. Oral history has been recognized as a way to help older people review and integrate their lives, to help young people to discover their heritage and their identity, and to enhance intergenerational harmony and understanding. Student journals have increasingly become part of school experience at all levels, from elementary education through advanced professional training, and the opportunity for reflection that they provide is viewed as a key ingredient in activating experiential learning. Recognition of the importance of storytelling in this sense continues to grow.

\section{HOW OUR STORIES CAN BE TOLD}

In my experience, one reason that our colleagues are often reluctant to write-to-tell their stories for publication is that we have been too limited in our thinking about how that can be done. Theoretical discussions, literature reviews, and research with statistical analysis, for example, are some ways in which our story can be told, but they are far from the only ways. Case studies (e.g., Kahn, 1990) represent another approach, as do first-person reports of significant experiences (e.g., Anglin, in press; Hopper, in press). Innovative program approaches can be described (e.g., Pirozak, 1989; Williams, 1987), issues can be illuminated through dialogue (e.g., VanderVen \& Davies-Jones, in press), and a story can be told by weaving together the observations of a variety of colleagues and others (e.g., Beker \& Barnes, in press). 
Sometimes, the best way to tell the story is, well, simply to tell the story, what we call fiction (e.g., Fewster, 1990; Krueger, 1987, 1990; Nault, 1987; Schreier, 1986; Weber, 1979), or through poetry (e.g., Fewster, 1985; Jesch, 1988; Petersen, 1984; Powers, 1982), or with the help of illustrations (e.g., Copans, 1987).

\section{SO WHO WANTS TO KNOW?}

The audience for our stories starts with ourselves and radiates out in concentric circles, sometimes encompassing the whole world. After half a century, for example, the story of Janusz Korczak, has been revived both within the literature of our field (e.g., Anglin, in press; Brendtro, in press) and in the broader English-speaking world (e.g., Lifton, 1988). Thus, his influence today exceeds that which he enjoyed when he was alive and engaged in the work for which he has become known; all that would have been lost had he and others not written about his work. It is worth noting that Korczak himself wrote and published widely, both stories for children and about how to work with children effectively.

Few of us are Korczaks, of course, nor are we expected to be. But each of us is charged with the task of being ourselves, as clearly and effectively as we can. For many of us, that process can be enhanced by writing, not only for publication, but even for ourselves. Journals and diaries can help us to think about what we do and to do it better in the future. Not only are they useful to look back on, helping to illuminate how far both we and those in our care have come, but the writing process itself helps us to organize our thoughts and often enables us to see things in new and perhaps more useful ways.

A second level involves required writing within our work settings, primarily reports on young people, programs, and the like. Here the challenge is to make such material as useful to ourselves and others as possible. When such tasks become routine and burdensome, seeming to be a waste of time, that should be examined as an indicator that something is amiss with the assignment or the way it is being used.

For those who want to try their hand at writing for others within a relatively small and protected circle, staff newsletters, house organs, and other agency publications often provide good opportunities. Where these do not exist, child and youth care workers may wish to do what they can to start them. They can be morale-builders and provide useful information to colleagues, build support among outside constituency groups, and offer a "test market" for material that might later be developed for wider publication. Child and youth care worker association newsletters issued by state, provincial, and other groups in 
the field also provide opportunities for publication, and they are usually open to and even anxious for material from colleagues who are new as well as from experienced writers.

Then there are the child and youth care work journals, such as this one, as well as those in allied fields that use material on child and youth care. As readers may have noticed, journals in both categories have proliferated in recent years, to the point where we now have several core journals (the exact number depending on how "core" is defined) and a growing number with a broader scope in which our field plays a significant part. An unintended consequence of all this is that often there are too few good manuscripts to go around!

As a result, not only are the journals committed by conviction and design to use material from practitioners, who are often new and inexperienced writers, but they are also pushed in that direction by the need for material. Rather than compromise standards, editors of most of the core journals (and sometimes others) frequently offer help to interested writers who have something to say. The opportunity this affords is unusual in a world where talented people in many other fields seem unable to break into print. Practitioners who are inexperienced writers have even produced manuscripts from time to time that have been published as books (e.g., Marek, 1987), so the opportunities are there.

\section{WHY BOTHER?}

Writing, especially writing for publication, can benefit the writer in several ways. Most basically, it is gratifying and fun to see one's by-line in print, and it should be; it represents not only an intrinsically satisfying, if sometimes difficult, effort, but also an external validation of success. As noted above, it can facilitate the effectiveness of the writer's own work, as well as that of his or her readers. And it can lead to increasing self-esteem and increasing recognition and advancement in a variety of ways. But these are far from the only reasons why child and youth care workers who have some interest in and impulse toward writing in this field should write (and the fact that you have read this far suggests you do). In all fields, but particularly in emerging ones such as this, the sharing of new approaches and practice wisdom is essential. Enhanced public support for our work and for the cause of children in general is needed as well, and we must find more and better ways to tell our story if this is to be achieved.

At its core, ours is a service occupation; we have taken on nothing less than the future of the world. Writing is one way, not always less 
important than our hands-on work with young people, in which that mission can be pursued. Help is available; the specifics have been outlined in these pages by Mark Krueger (e.g., 1989) over the years. As has been noted elsewhere (Beker \& Barnes, in press), the Talmud suggests that, "It is not yours to complete the work, but neither are you free to take no part in it." "If not now," another passage adds, "when?"

\section{REFERENCES}

Anglin, J. P. (in press). "I know I don't have to apologize for crying": When our history becomes our experience. Child and Youth Care Quarterly, 19.

Baizerman, M. (1987). Guest Editorial - Orality and talk: Youthwork in youth agencies. Child and Youth Care Quarterly, 16 (3), 149-150.

Beker, J., \& Barnes, F. H. (in press). The educateur returns to America: Approaching the development of professional child and youth care cross-culturally through ILEX. Child and Youth Care Quarterly, 19.

Brendtro, L. K. (in press). Powerful pioneers in group care: A look at our roots and heritage. Child and Youth Care Quarterly, 19.

Copans, S. A. (1987). The adventures of Aliana. Child and Youth Care Quarterly, 16, 227-234.

Eisikovitz, Z., \& Beker, J. (1983). Beyond professionalism: The child and youth care worker as craftsman. Child Care Quarterly, 12, 93-120.

Fewster, G. (1985). A child is dead. Journal of Child Care, 2(3), v-vi.

Fewster, G. (1990). Being in child care: A journey into self. New York: Haworth. (Also published as Child \& Youth Services, 14, (2).)

Hopper, S. (in press). "I never thought I'd make it quite this far": A personal journey in international understanding. Child and Youth Care Quarterly, 19.

Jesch, J. (1988). Viewing point. Journal of Child and Youth Care Work, 4, 99.

Kahn, T. J. (1990). The adolescent transsexual in a juvenile corrections institution: A case study. Child and Youth Care Quarterly, 19(1).

Krueger, M. A. (1990). Floating. Washington, DC: The Child Welfare League of America.

Krueger, M. A. (1990). In motion. Washington, DC: The Child Welfare League of America. 
Lifton, B. J. (1988). The king of children. New York: Farrar, Straus, \& Giroux.

Marek, E. (1987). The children at Santa Clara. New York: Viking Penguin.

Nault, S. (1987). Maybe I'm not cut out to be a child care worker after all. Journal of Child and Youth Care Work, 3, 81-86.

Petersen, R. W. (1984). A tribute to Albert I. Trieschman. Child Care Quarterly, 13, 159-160.

Pirozak, E. S. (1989). "Cards by Kids"*: A project of art as therapy. Journal of Child and Youth Care Work, 5, 33-37. ( ${ }^{*}$ Copyright.)

Powers, D. (1982). One way only. Residential Group Care and Treatment, 1,(1), 21.

Schreier, F. (1986). Death of a child care worker. Journal of Child and Youth Care Work, 2, 63-68.

VanderVen, K., \& Davies-Jones, H. (in press). Training and education for child and youth care practice: The view from both sides of the Atlantic. Child and Youth Care Quarterly, 16, 241-248. 